\title{
The vegetal biomembrane in the healing of chronic venous ulcers
}

Biomembrana vegetal na cicatrização de úlceras venosas crônicas

\author{
Marco Andrey Cipriani Frade ${ }^{1}$ \\ Joaquim Coutinho Netto ${ }^{3}$ \\ Norma Tiraboschi Foss ${ }^{5}$
}

\author{
Raimunda Violante Campos de Assis $^{2}$ \\ Thiago Antônio Moretti de Andrade ${ }^{4}$
}

\begin{abstract}
BACKGRound: The vegetal biomembrane has been used to treat cutaneous ulcers.
Овлестіvеs: To assess the role of the vegetal biomembrane on the chronic venous ulcers treatment compared to treatment with collagenase cream.

Methods: Fourteen patients were selected to be treated with vegetal biomembrane and 7 with Fibrase ${ }^{\circledast}$ (CONTROL), followed clinically and photographically by the Wound Healing Index by ImageJ during 120 days and biopsied on the $1^{\text {st }}$ and $30^{\text {th }}$ days for histological examination.

RESULTS: The vegetal biomembrane was better in promoting healing of the ulcers, especially on the inflammatory phase, confirmed by abundant exudation and wound debridement than the CONTROL group, on the $30^{\text {th }}$ day. There was a greater tendency to angiogenesis followed by re-epithelialization with highest wound healing index on the $90^{\text {th }}$ and $120^{\text {th }}$ days.

CONCLUSION: A combined analysis of clinical and histopathological findings suggests that the vegetal biomembrane acted as a factor inducing wound healing, especially on the inflammatory phase, confirmed by abundant exudation of the lesions promoting the transformation of the microenvironment of the chronic venous ulcers, and also stimulating angiogenesis and subsequent re-epithelialization.
\end{abstract}

Keywords: Biological dressings; Latex; Leg ulcer; Wound healing

Resumo: Fundamentos: A biomembrana vegetal tem sido usada para tratamento de úlceras cutâneas.

Oвјетіvos: Avaliar a ação da biomembrana vegetal no tratamento de úlceras venosas crônicas, comparando-a ao tratamento à base de colagenase.

MÉTODOS: Foram selecionados 14 pacientes tratados com biomembrana vegetal e sete com Fibrase ${ }^{\circledR}$ (grupo controle), acompanhados clínico-fotograficamente pelo índice de cicatrização das úlceras (ICU) por 120 dias, por meio do software ImageJ, e biopsiados no primeiro e $30^{\circ}$ dias para estudo histopatológico.

RESUlTADOS: A biomembrana vegetal foi superior em relação ao controle na cicatrização das úlceras no $30^{\circ}$ dia, especialmente na fase inflamatória, confirmada pela exsudação abundante e pelo desbridamento. Houve tendência superior à angiogênese seguida de reepitelização com maiores ICUs no $90^{\circ} \mathrm{e} 120^{\circ}$ dias.

ConCLUSÃo: A análise conjunta dos achados clínicos e histopatológicos sugere que a biomembrana vegetal atuou como um fator indutor da cicatrização, especialmente na fase inflamatória, confirmada pela exsudação abundante das lesões, promovendo a transformação do microambiente das úlceras venosas crônicas e estimulando a angiogênese e a posterior reepitelização.

Palavras-chave: Cicatrização; Curativos biológicos; Látex; Úlcera da perna

Received on 04.12.2009.

Approved by the Advisory Board and accepted for publication on 13.01.2011.

* Work performed at the Outpatient Clinic of Neurovascular Ulcer of the Dermatology of the Hospital das Clínicas of the Faculdade de Medicina de Ribeirão Preto of the Universidade de São Paulo (FMRP - USP) Discipline of Dermatology, Medical School of the Universidade Federal de Juiz de Fora (FM - UFJF) Juiz de Fora (MG), Brasil.

Conflict of interest: None / Conflito de interesse: Nenbum

Financial funding / Suporte financeiro: Coordination and Improvement of Tertiary Personnel (Coordenação de Aperfeiçoamento de Pessoal de Nível Superior - CAPES) PhD Scholarship period 2000/2003; Teaching, Research and Assistance Support Foundation (Fundação de Apoio ao Ensino Pesquisa e Assistência) Hospital das Clínicas of the Faculdade de Medicina de Ribeirão Preto of the Universidade de São Paulo (FAEPA-HC-FMRP/USP)

PhD (Post Doctoral) - Medical Professor Division of Dermatology of the Department of Internal Medicine of the Faculdade de Medicina de Ribeirão Preto of the Universidade de São Paulo (FMRP-USP) - Fundação de Apoio ao Ensino Pesquisa e Assistência (FAEPA) - Ribeirão Preto (SP), Brasil.

Medical Professor - Department of Pathology of the Universidade Federal de Juiz de Fora (UFJF) - Juiz de Fora (MG), Brasil. - in memoriam

Assistant Professor - Departament of Biochemistry and Immunology of the Faculdade de Medicina de Ribeirão Preto of the Universidade de São Paulo (FMRPUSP) - Ribeirão Preto (SP), Brasil.

Master - PhD Candidate - Post Graduation Program in Internal Medicine of the Faculdade de Medicina de Ribeirão Preto of the Universidade de São Paulo (FMRP-USP) - Ribeirão Preto (SP), Brasil.

Assistant Professor - Division of Dermatology of the Department of Internal Medicine of the Faculdade de Medicina de Ribeirão Preto of the Universidade de São Paulo (FMRP-USP) - Ribeirão Preto (SP), Brasil. 


\section{INTRODUCTION}

Leg ulcers are a syndrome characterized by circumscript or irregular loss of tegument (epidermis and/or dermis) that involves the lower extremities, usually associated with dysfunction of the arterial or venous vascular system. ${ }^{1}$

The leg ulcers can be classified according to its ethiology in ulcers due to venous insufficiency (venous ulcers) corresponding to 80 to $85 \%$ of the cases, arterial insufficiency (arterial ulcer) in 5 to $10 \%$ and the remaining due to neuropathies (neuropathic ulcer/diabetic foot). They can also be caused by trauma, neoplasia, infections, panniculites and pyoderma gangrenosum. ${ }^{2}$

The prevalence of leg ulcers varies from $0.18 \%$ to $1.3 \%$ of the adult population. ${ }^{2,3}$ They develop most commonly in the elderly population and its prevalence has been accentuating with the increase of life expectance worldwide, becoming frequent on medical daily life.

The most popular treatment form of venous ulcers is done with compressive bandages, introduced by Unna (1885). ${ }^{4}$ There are various types of dressings used nowadays for this type of treatment, with different indications, advantages and disadvantages. The choice of dressing must be based essentially on factors of efficacy and cost, so that the patient can maintain it and thus achieve a satisfactory result, as the lesions have a long period of evolution and the healing is slow in most cases.

The healing of the ulcers is a sequence of complex biologic events that involve cellular and molecular processes, like the recruiting of leucocytes, inflammation, angiogenesis and collagen deposition and reepithelialization. $^{5}$

Amongst the various therapeutic options for leg ulcers, the vegetal biomembrane (VBM), from the Hevea brasiliensis rubber tree, stands out. A biocompatible material, it was originally developed by the Ribeirão Preto Medical School (Faculdade de Medicina de Ribeirão Preto) - Universidade de São Paulo/Brasil. Experiments with dogs showed that the material was an important inducer of healing of the oesophageal walls, with significant increase of the vascularisation (neoangiogenesis), epithelialization (pseudostratified epithelium), submucosal glandular neoformation and formation of muscle fibers. ${ }^{6}$ In flebopathic ulcers evident signs of stimulus to clinical and histological granulation were seen from the $15^{\text {th }}$ day of treatment with the VBM, with accentuated decrease of the symptoms, including resolution of the pain. ${ }^{7}$

There are current reports that the VBM performs in various stages of the healing process of the leg ulcers, like on the removal of the necrotic tissue (debridement), proliferation of granulation tissue (angiogenesis) and re-epithelialization, especially in chronic ulcers of diabetic patients who have complications like diabetic microangiopathy, high blood pressure and surgical difficulties. ${ }^{7.9}$ However little is known about its real mechanism of action. ${ }^{8}$

In view if the already demonstrated biocompatibility of the VBM, preliminary results from case reports and the lack of knowledge of its mechanism of action, this study endeavours to evaluate the clinical and histological alterations of the tissue repair of the venous ulcers in the presence of the vegetal biomembrane from the Hevea brasiliensis rubber tree, compared to the conventional treatment with colagenase (Fibrase $\left.^{\circledR}\right)^{7,8,9}$

\section{PATIENTS AND METHODS Patients}

After signing the consent form, 21 patients from the Outpatients Clinic of leg ulcers of the Hospital Universitário of the Universidade Federal de Juiz de Fora - Juiz de Fora-MG and UBDS Alexandre Fleming Ribeirão Preto-SP were randomly selected and thus distributed: 07 patients to the colagenase group (CONTROL GROUP) and 14 to the vegetal biomembrane group (VBM GROUP). All patients were selected by the presence of venous leg ulcer for more than 2 months, diagnosed according to clinical signs like: varicose veins, hyperpigmentation, lipodermatosclerosis, signs of eczema and pruritus. Patients with uncontrolled high blood pressure, diabetes or other systemic disease were excluded. The clinical data from the patients and characteristics of the ulcers are described on table 1.

All the selection and participation of the patients are in agreement with the norms established by the Research Ethics Committee (REC) of the HCFMRP-USP according to the processes 4875/2001 and $11722 / 2003$ respectively.

\section{METHODS}

The leg ulcers were cleaned with saline solution at $0.9 \%$ only and dried with gauze, getting ready to receive the designated dressing.

- Control dressing: daily topical application of fibrinolisine associated with chloramphenicol $\left(\right.$ Fibrase $^{\circledR}$ ), gauze and bandage.

- VBM dressing: performed every second day, at home, with VBM applied to the bed of the ulcer, not going over the limits of normal skin, gauze and bandages.

\section{Clinical evaluation}

After filling up the protocol at consultation, the ulcers were photographed on days 1, 30, 60 and 90 for clinical follow-up. The images were analysed by 
TABLE 1: Clinical characterization of the patients and respective leg ulcers of the patients of the control and VBM groups

\begin{tabular}{|c|c|c|c|c|c|}
\hline \multicolumn{2}{|c|}{ Clinical Characteristics } & \multicolumn{2}{|c|}{ CONTROL GROUP $(\mathbf{n}=7)$} & \multicolumn{2}{|c|}{ VBM GROUP $(n=14)$} \\
\hline & & $\mathbf{n}$ & $\%$ & & $\%$ \\
\hline \multirow{4}{*}{ Age (years) } & Average & 61.6 & - & 64.1 & - \\
\hline & Median & 70 & - & 64.5 & - \\
\hline & $1^{\text {st }}$ Quartile & 51.4 & - & 57 & - \\
\hline & $2^{\text {nd }}$ Quartile & 72 & - & 70.8 & - \\
\hline \multirow[t]{2}{*}{ Sex } & Masculine & - & - & 5 & 35.7 \\
\hline & Feminine & 7 & 100 & 9 & 64.3 \\
\hline \multirow[t]{2}{*}{ Color } & White & 3 & 42.9 & 11 & 78.6 \\
\hline & Non white & 4 & 57.1 & 3 & 21.4 \\
\hline \multirow{4}{*}{ Job } & Retired & 6 & 85.7 & 8 & 57.1 \\
\hline & Home duties & - & - & 4 & 28.6 \\
\hline & Peasant & - & - & 2 & 14.3 \\
\hline & Merchant & 2 & 14.3 & - & - \\
\hline \multirow{2}{*}{$\begin{array}{l}\text { Associated } \\
\text { diseases }\end{array}$} & CVI & 4 & 57.1 & 6 & 42.9 \\
\hline & $\mathrm{CVI}+\mathrm{HBP}$ & 3 & 42.9 & 8 & 57.1 \\
\hline \multirow{4}{*}{$\begin{array}{l}\text { Duration } \\
\text { (months) }\end{array}$} & Average & 116 & - & 102.6 & - \\
\hline & Median & 108 & - & 36 & - \\
\hline & $1^{\text {st }}$ Quartile & 24 & - & 8 & - \\
\hline & $2^{\text {nd }}$ Quartile & 204 & - & 105 & - \\
\hline \multirow{2}{*}{$\begin{array}{l}\text { Previous history } \\
\text { of ulcers }\end{array}$} & $1^{\text {st }}$ episode & 5 & 71.4 & 7 & 50.0 \\
\hline & Relapse & 2 & 28.6 & 7 & 50.0 \\
\hline
\end{tabular}

CVI $=$ Chronic Venous Insufficiency; HBP $=$ High Blood Pressure

the ImageJ 1.36 (U.S. National Institutes of Health, Bethesda, MD, USA) software and subsequently the normalized Ulcer Healing Index (UHI), described as the ration of the difference between the initial area and the area on day 30 over the initial area, as proposed by Caetano et al., (2009), was calculated. ${ }^{10-13}$

Additionally the semi-quantitative analyses of the photographed images was performed by two different observers who analysed the variables debris/necrosis, granulation tissue and re-epithelialization tissue individually and adopted the crosses criteria: (+) when the relative fraction of the variable corresponded to up to $1 / 3$ of the ulcerated area; $(++)$ up to $2 / 3$ and $(+++)$ more than $2 / 3$ of the ulcerated area.

\section{Histopathologic evaluation}

The patients were biopsied on days $1^{\text {st }}$ and $30^{\text {th }}$ of the treatment. A semi-quantitative analysis of the specimens was chosen, using the crosses system as described on chart 1 .

\section{Statistical analyses}

An exploratory statistical analysis of the variables age and duration of the patients' ulcers was done, considering the average, median and interquartile deviations. For comparative analysis of the continuous variables of the VBM and CONTROL groups the
Mann-Whitney test was used for non-parametric samples. For the categorical variables like progressive, regressive or indifferent, the analysis between the groups was done by the Mc Nemar test applied to the results obtained as progressive and regressive. The level of statistical significance was set at $\mathrm{p}<0.05$.

\section{RESULTS}

\section{Clinical Characterization}

In terms of location of the ulcers it was noted that they were more frequent $(85.8 \%)$ on the lower distal third in both groups.

As for the duration of the ulcers, the median on the CONTROL GROUP was 108 months while on the VBM it was 36 months (Table 1).

In most patients of the CONTROL GROUP $(5 / 7)$, the leg ulcers corresponded to the first episode and in 2 of them they were relapsing, while on the VBM group only half corresponded to the first episode (Table 1).

The period of treatment varied, and the patients of the CONTROL GROUP were followed by 30 days with use of topical Fibrase ${ }^{\circledast}$. On the VBM GROUP the follow-up period was at least 30 days in all 
CHART 1: Classification by crosses of the semi quantitative histopathological examination

\begin{tabular}{|c|c|c|}
\hline Parameter & Crosses & Location/pattern \\
\hline \multirow[t]{3}{*}{ Necrosis } & + & On the upper $1 / 3$ of the dermis \\
\hline & ++ & All of the dermis \\
\hline & +++ & Up to the subcutaneous tissue \\
\hline \multirow[t]{3}{*}{ Inflammation } & + & Borders of the lesion \\
\hline & ++ & $2 / 3$ of the specimen \\
\hline & +++ & The whole specimen \\
\hline \multirow[t]{3}{*}{ Angiogenesis } & + & Capillary vessels with thin walls, 1 or 2 endothelial cells, borders of the lesion \\
\hline & ++ & $\begin{array}{l}\text { Capillary vessels with wall thickness twice the previous, swollen endothelium, in } \\
2 / 3 \text { of the lesion }\end{array}$ \\
\hline & +++ & Thick wall vessels, swollen endothelium, in the whole specimen \\
\hline \multirow[t]{3}{*}{ Elastosis } & + & Delicate elastic fibers, occasional \\
\hline & ++ & Thin and thick elastic fibers in equal proportion \\
\hline & +++ & Thick elastic fibers in the whole specimen \\
\hline \multirow[t]{3}{*}{ Collagenic fibrosis } & + & Delicate and occasional collagen fibers \\
\hline & ++ & Delicate and thick collagen fibers, occasional \\
\hline & +++ & Thick collagen fibers, characterizing scar \\
\hline \multirow{3}{*}{$\begin{array}{l}\text { Fibroblastic } \\
\text { proliferation }\end{array}$} & + & Occasional fibroblasts. Predomination of acute inflammatory cells \\
\hline & ++ & Fibroblasts and inflammatory cells in equal proportion \\
\hline & +++ & Fibroblastic predomination in the whole specimen \\
\hline
\end{tabular}

patients, 60 days in 11 and 90 days in 5 patients.

In terms of absolute areas it was noted that the CONTROL GROUP had an average area of $9.37 \mathrm{~cm}^{2}$ and the VBM GROUP $13.19 \mathrm{~cm}^{2}$. Both groups were statistically similar $(p=0.43)$ under the Mann-Whitney test for non parametric samples.

In terms of the analysis of the Ulcer Healing Index (UHI), no statistically significant difference was observed between the CONTROL and VBM GROUPS $(p=0.39)$ on the $30^{\text {th }}$ day of treatment. However, dur- ing the follow-up of the ulcers treated with VBM there was a progressive increment of the UHI on the $60^{\text {th }}$, $90^{\text {th }}$ and $120^{\text {th }}$ day (Figure 1).

On the semi-quantitative analysis it was observed that only the variable fibrine/debris had a statistically significant decrease on the VBM group $(p=0.013)$ in relation to the control group, besides a tendency to progressive angiogenesis on the VBM group, as described on table 2 and clinically demonstrated with figure 2 .

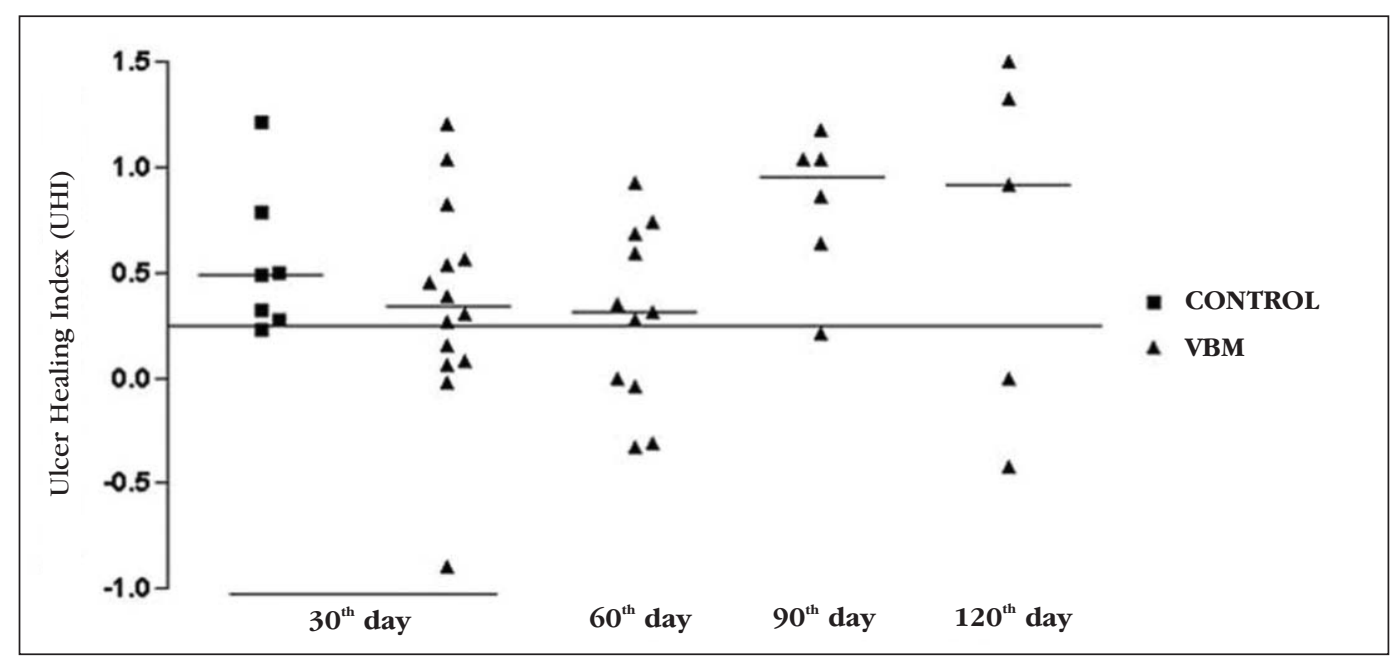

Figure 1: Percentage of reduction of the areas of the ulcers on the CONTROL and VBM GROUPS during follow-up 
TABLE 2: Result of the clinical-photographic analysis of the patients of the control and VBM groups after 30 days of treatment

\begin{tabular}{llllll}
\hline Parameter & Evolution & \multicolumn{2}{c}{ CONTROL GROUP $(\mathbf{n}=7)$} & \multicolumn{2}{c}{ VBM GROUP $(\mathbf{n}=\mathbf{1 4})$} \\
& & Number & $\%$ & Number & $\%$ \\
\hline \multirow{2}{*}{ Fibrine } & Regressive * & 2 & 28.6 & 11 & 78.6 \\
& Progressive & 1 & 14.3 & 1 & 7.0 \\
& Indifferent & 4 & 57.0 & 2 & 14.0 \\
Granulation & Regressive & 0 & 0 & 1 & 7,0 \\
& Progressive & 3 & 43.0 & 8 & 56.0 \\
& Indifferent & 4 & 57.0 & 5 & 35.0 \\
Re-epithelialization & Regressive & 0 & 0 & 0 & 0 \\
& Progressive & 3 & 43.0 & 6 & 42.0 \\
& Indifferent & 4 & 57.0 & 8 & 56.0 \\
\hline
\end{tabular}

$* \mathrm{p}=0.013$ for monocaudal tests.

As for the semi-quantitative histological evaluation before and after treatments, the histological evolution of the ulcers was characterized as: regressive (decrease of the number of crosses), progressive (increase of the number of crosses) and indifferent, and the results were analysed by the modified Mc Nemar test. It was observed that the treatment with VBM has a tendency to regression in terms of necrosis and inflammation and progression in terms of angiogenesis when compared with the CONTROL group. (Table 3).

\section{DISCUSSION}

Both groups were homogeneous in terms of age $(p=0.45)$, location and duration of the ulcers $(p=0.18)$, although the CONTROL GROUP had a slightly longer duration than the VBM GROUP in 7.1 months, data that confirms the reports from Nelzen et al., (1991) and Frade et al., (2005). ${ }^{14,15}$

On the other hand, only $2.0(28 \%)$ patients of the control group were relapsing cases as opposed to $7.0(50 \%)$ on the VBM group and the average area of the ulcers on the CONTROL GROUP was slightly smaller than that of the VBM GROUP $(p=0.43)$.

On the clinic-photographic analysis of the treatment of the ulcers the results showed the debriding potential of the VBM by the regression of the variable fibrine/debris higher that of the CONTROL GROUP

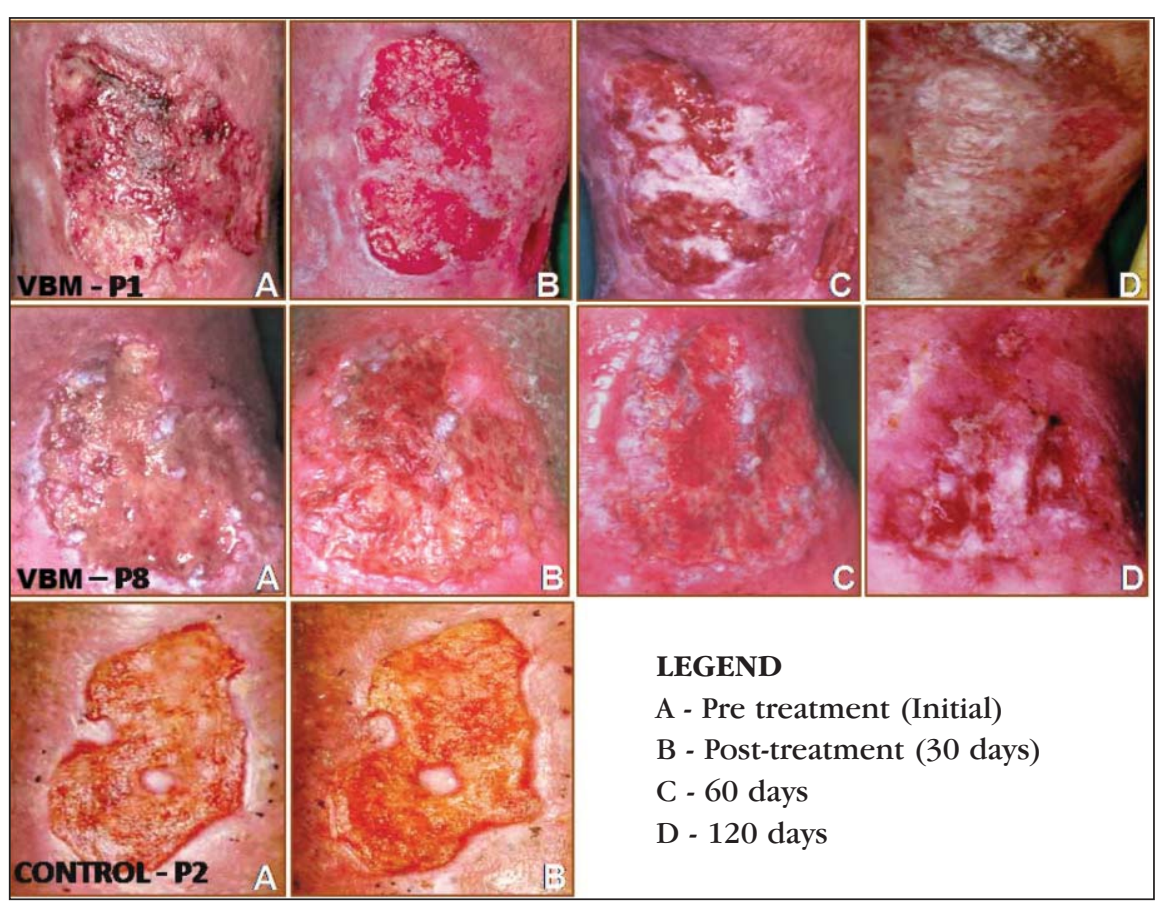

Figure 2: Clinical evolution of the venous ulcers of patients 1 and 8 of the VBM GROUP and patient 2 of the CONTROL GROUP 
TABLE 3: Histopathological analysis of the patients of the control and VBM groups (Mc Nemar Test)

\begin{tabular}{|c|c|c|c|c|c|c|c|}
\hline \multirow[t]{2}{*}{ Parameter } & \multirow[t]{2}{*}{ Evolution } & \multicolumn{2}{|c|}{ CONTROL } & \multicolumn{2}{|c|}{ VBM - 30 days } & \multicolumn{2}{|c|}{ VBM - 30 days } \\
\hline & & n. & $\%$ & n. & $\%$ & n. & $\%$ \\
\hline \multirow[t]{3}{*}{ Necrosis } & Regressive & 1 & 20 & 4 & 58.3 & 1 & 20 \\
\hline & Progressive & 0 & 0 & 1 & 8.3 & 3 & 60 \\
\hline & Indifferent & 4 & 80 & 7 & 33.3 & 1 & 20 \\
\hline \multirow[t]{3}{*}{ Inflammation } & Regressive & 2 & 40 & 6 & 50 & 5 & 100 \\
\hline & Progressive & 1 & 20 & 0 & 0 & 0 & 0 \\
\hline & Indifferent & 2 & 40 & 6 & 50 & 0 & 0 \\
\hline \multirow[t]{3}{*}{ Angiogenesis } & Regressive & 0 & 0 & 3 & 25 & 0 & 0 \\
\hline & Progressive & 2 & 40 & 5 & 41.7 & 2 & 40 \\
\hline & Indifferent & 3 & 60 & 4 & 33.3 & 3 & 60 \\
\hline \multirow[t]{3}{*}{ Elastosis } & Regressive & 0 & 0 & 2 & 16.7 & 0 & 0 \\
\hline & Progressive & 4 & 80 & 9 & 75 & 2 & 40 \\
\hline & Indifferent & 1 & 20 & 1 & 8.3 & 3 & 60 \\
\hline \multirow{3}{*}{$\begin{array}{l}\text { Collagenic } \\
\text { fibrosis }\end{array}$} & Regressive & 0 & 0 & 2 & 16.7 & 3 & 60 \\
\hline & Progressive & 3 & 60 & 5 & 41.7 & 1 & 20 \\
\hline & Indifferent & 2 & 40 & 5 & 41.7 & 1 & 20 \\
\hline \multirow{3}{*}{$\begin{array}{l}\text { Fibroblastic } \\
\text { proliferation }\end{array}$} & Regressive & 0 & 0 & 4 & 33.3 & 2 & 40 \\
\hline & Progressive & 4 & 80 & 3 & 25 & 1 & 20 \\
\hline & Indifferent & 1 & 20 & 5 & 41.7 & 2 & 40 \\
\hline
\end{tabular}

$(\mathrm{p}=0.013)$. This result was confirmed by the histopathological study, with a tendency to regression of the necrosis and inflammation variables on the VBM GROUP also superior than the CONTROL GROUP.

The increase of the ulcer exudates at the beginning of the treatment was reported and observed by the patients on the VBM GROUP, which gradually decreased with the use of dressings, probably related to the inflammatory activity triggered by the VBM, which increases the vascular permeability and consequent intense exudation. As for its mechanism of action it was proposed by Andrade (2007) that VBM has an intense inflammatory activity, at the cost of polymorphonucleocytes, histologically demonstrated by the increase of the myeloperoxidase, as well as by higher expression of IL-1 $\beta$ and iNOS at immunohistochemistry. ${ }^{16}$

VBM demonstrated a superior tendency to progression on the CONTROL of the induction of granulation tissue, although without statistical difference. At histopathological examination the results in relation to angiogenesis were similar between both groups on the $30^{\text {th }}$ day of follow-up.

The vascular neoformation (granulation) that represents the initial stage of the tissue formation of the healing process was well developed in many patients of the VBM GROUP, reaching the point of accentuated granulation (hypergranulation). On the other hand, on the control group the granulation stimulus was very mild and no case of hypergranulation was observed.

The clinical analyses of some patients of the VBM GROUP, showed that the treatment led to an intense vessel formation, represented by exuberant granulation around the $30^{\text {th }}$ day, with a light red color granulation tissue (neoangiogenesis). However, with the progression of the treatment the tissue became more compact, accentuating the color to a darker red (collagenesis) at around the second month of treatment, which represents the tissue transformation promoted by the VBM, highlighting its importance as an inductor of healing tissue both on the tissue formation and on the tissue remodelling stages (Figure 2).

In terms of re-epithelialization, a phenomenon related to the size of the ulcers, there was no statistical difference between the treatments on the CONTROL and VBM, certainly due to the short follow-up period (30 days) of the CONTROL GROUP. However, on the follow-up of the VBM GROUP patients beyond the $30^{\text {th }}$ day, Healing Ulcer Index higher than 0.5 on the $90^{\text {th }}$ and $120^{\text {th }}$ day confirm the role of VBM on the re-epithelialization stage of the chronic venous ulcers, as previously described Frade et al., (2001). ${ }^{15}$

It is important to stress that the main limitation of the study was that the patients of the CONTROL 
GROUP did not want to continue the treatment based on Fibrase ${ }^{\circledast}$ due to the expectation of using the alternative treatment (VBM), which impaired the clinicaltherapeutic analyses after the $30^{\text {th }}$ day.

As for the application of the dressing, the information from the patients of the VBM GROUP about the convenience of the application, due to less frequent changes and, mostly, the non-adherence of the dressing to the bed of the ulcer, related to the exudation induced by the VBM, associated with the absence of pain and tissue damage during the changes, was relevant. As for the CONTROL GROUP the changes were done on a daily basis, accompanied by pain with the removal of the dressing and, generally, traumatic to the healing process.

The joint analyses of the clinical and histopathological findings suggest that the vegetal biomembrane acted as an inductor factor of the healing process, especially on the inflammatory stage,

\section{REFERENCES}

1. Carvalho MT, Bastos SM, Frade MA, Gamonal AC. Úlceras de perna. In: Gamonal AC. Dermatologia elementar - compêndio de dermatologia. Juiz de Fora; 2000. p. 115-7.

2. Phillips TJ. Chronic cutaneous ulcers: etiology and epidemiology. J Invest Dermatol. 1994;102:38S-41S.

3. Sampaio SA, Rivitti EA. Dermatologia. 1. ed. São Paulo: Guanabara Koogan; 1998.

4. Unna PG. Ueber paraplaste eine neue form medikamentoser pflaster. Wien Med Wochenschr. 1896;43:1854-9.

5. Gurtner GC, Werner S, Barrandon Y, Longaker MT. Wound repair and regeneration. Nature. 2008;453:314-21.

6. Mrué F. Substituição do esôfago cervical por prótese biossintética de látex. Estudo experimental em cães [dissertação]. São Paulo (SP): Faculdade de Medicina de Ribeirão Preto da Universidade de São Paulo; 1996.

7. Frade MA, Valverde RV, de Assis RV, Coutinho-Netto J, Foss NT. Chronic phlebopathic cutaneous ulcer: a therapeutic proposal. Int J Dermatol. 2001;40:238-40.

8. Frade MA, Salathiel AM, Mazzucato EL, Coutinho-Netto J, Foss NT. A natural biomembrane as a new porposal for the treatment pf pressure ulcers. Med Cutan Iber Lat Am. 2006;34:133-8

9. Frade MA, Cursi IB, Andrade FF, Coutinho-Netto J, Barbetta FM, Foss NT. Management of diabetic skin wounds with a natural latex biomembrane. Med Cutan Iber Lat Am. 2004;32:157-62.

10. Caetano KS, Frade MA, Minatel DG, Santana LA, Enwemeka CS. Phototherapy improves healing of chronic venous ulcers. Photomed Laser Surg. 2009;27:111-8.

11. Collins T. ImageJ for microscopy. Biotechniques. 2007;43(1 Suppl):25-30.

12. Minatel DG, Enwemeka CM, Franca SC Frade MA. Fototerapia (LEDs $660 / 890 \mathrm{~nm}$ ) no tratamento de ulceras de perna em pacientes diabeticos: estudo de caso. An Bras Dermatol. 2009;84:279-83. confirmed by the abundant exudates of the lesions, promoting the transformation of the microenvironment of the chronic venous ulcers, stimulus to angiogenesis and subsequent re-epithelialization.

\section{CONCLUSIONS}

The vegetal biomembrane was important for the induction of the healing, especially on the inflammatory stage, confirmed by the abundant exudation and debridement of the ulcers in relation of the control treatment of chronic venous ulcers, which seems to be directly related to the intense vascular formation followed by re-epithelialization.

\section{ACKNOWLEDGMENT}

We are thankful CAPES e FAEPA-HCFMRP-USP for the financial support.
13. Minatel DG, Frade MA, Franca SC, Enwemeka CS. Phototherapy promotes healing of chronic diabetic leg ulcers that failed to respond to other therapies. Lasers Surg Med. 2009;41:433-41

14. Nelzén 0, Bergqvist D, Lindhagen A. Leg ulcer etiology--a cross sectional population study. J Vasc Surg. 1991;14:557-64.

15. Frade MA, Cursi IB, Andrade FF, Soares SC, Ribeiro WS, Santos SV, et al. Úlceras de perna: um estudo de casos em Juiz de Fora-MG (Brasil) e região. An Bras Dermatol. 2005;80:41-6.

16. Andrade TAM, IYER A, Das PK, Foss NT, Garcia SB,COUTINHO-NETTO J, Jordão-Jr $A A$, Frade MAC. The inflammatory stimulus of a natural latex biomembrane improves healing in mice. Brazilian Journal of Medical and Biological Research, v. 44, p. 10361047, 2011.
MAILING ADDRESS / ENDEREÇO PARA CORRESPONDÊNCIA : Marco Andrey Cipriani Frade Av. Bandeirantes, 3.900, Bairro Monte Alegre 14049-900 Ribeirão Preto, SP, Brazil

Pbone.: 55 (16) 3602-2447; fax: 55 (16) 3633-0236

E-mail:mandrey@fmrp.usp.br

How to cite this article/Como citar este artigo: Frade MAC, Assis RVC, Coutinho-Netto J, Andrade TAM, Foss NT. The vegetal biomembrane in the healing of chronic venous ulcers. An Bras Dermatol. 2012;87(1):45-51. 